\title{
Anuran inventory in a locality of the buffer area of La Amistad International Park, Costa Rica: pilot study for Citizen Science application
}

Diego Gómez-Hoyos ${ }^{1,2}$, Rafael Méndez-Arrieta ${ }^{3}$, Adams Méndez-Arrieta ${ }^{3}$, Rocío Seisdedos-de-Vergara1 ${ }^{1}$ Juan Abarca $^{4}$, Cesar Barrio-Amorós ${ }^{5} \&$ José González-Maya ${ }^{1}$

1 ProCAT Internacional \& Fundación Sierra to Sea Costa Rica. Las Alturas, Puntarenas, Costa Rica.

2 Grupo de Estudio en Herpetología \& Grupo de Investigación en Estadística, Universidad del Quindío, Armenia, Quindío, Colombia.

3 Recuperación y Estudio de Abejas Nativas. Ruta Municipal 135, Puntarenas, Costa Rica.

4 Centro de Investigación en Estructuras Microscópicas. Universidad de Costa Rica, San José, Costa Rica.

5 DocFrog Expeditions, Uvita, Costa Ballena, Costa Rica.

\section{Correspondence}

D. Gómez-Hoyos

E-mail: dgomez@procat-conservation.org

Received: 29 August 2017

Accepted: 9 April 2018

Published on-line: 10 May 2018

\section{Resumen}

Inventario de anuros en una localidad del área de amortiguamiento del Parque Internacional La Amistad, Costa Rica: estudio piloto para aplicación de ciencia ciudadana

Presentamos un inventario de anuros en la zona de amortiguamiento del Parque Internacional La Amistad, realizado por personas locales. Discutimos los resultados en torno al marco de Ciencia Ciudadana y su aplicación para estudios de anfibios, así como el nivel de incertidumbre de la identificación de especies por fotografías. Registramos 15 especies de anuros, de las cuales seis fueron identificadas de forma confiable, la estimación de riqueza extrapolada fue de $\sim 20$ especies. Reconocemos la extensión altitudinal de Scinax boulengeri. En muchas áreas rurales del Neotrópico los ciudadanos que podrían involucrarse en investigación son campesinos. Además, los datos que pueden proveer son de áreas aisladas por lo que pueden ser útiles para contribuir en el conocimiento de los anfibios.

Palabras clave: Anfibios, Investigación participativa, Riqueza, Ciencia ciudadana.

\begin{abstract}
We present an anuran inventory in the buffer area of La Amistad International Park performed by local people. Results are discussed around the Citizen Science framework and their application for amphibian studies, as well as the uncertainty level of the species' identification by photographs. Fifteen anuran species were recorded, of which six where considered to be reliably identified, and extrapolated species richness estimate was $\sim 20$ species. We recognized the altitudinal extension range of Scinax boulengeri. In many rural areas in the Neotropic the citizens that could be involved in research are farmers. Also, the data they can provide is usually from isolated areas, and therefore can be useful for contributing on amphibian knowledge.
\end{abstract}

Key words: Amphibians, Participative research, Richness, Citizen science. 


\section{Introduction}

Citizen science is a research practice in which interested and trained citizens participate in science voluntarily by collecting data (Bhattacharjee 2005, Wiggins et al. 2013). This practice has increased and can have important implications for conservation (Burgess et al. 2017). Data obtained by citizens have a considered potential value, for example, for detecting changes in species' distribution (Schmeller et al., 2009).

Successful citizen science projects involving wild fauna have been mainly developed with birds as a target (Lepczyk 2005, Sullivan et al. 2009, 2014, Menacho-Odio 2015). Other taxonomic groups have been included in citizen science and community-based monitoring initiatives such as insects and plants, especially in North America, Europe and Oceania (Chandler et al. 2017, Palmer et al. 2017). Initiatives in Central and South America are scarce, as well as for amphibians in general around the world (Chandler et al. 2017). However, important initiatives with amphibians have been developed, including the Global Amphibian Bioblitz (AmphibiaWeb 2018) and Catawba River Coverboard Program (Pittman \& Dorcas 2006).

Amphibians have additional challenges for citizen science application, especially in the accurate species identification. Although visual aid such as photographs could be useful as a preliminary approach to assessing the richness of a locality, it should always be corroborated by qualified herpetologists, with the purpose of avoiding bias and mistakes. Aceves-Bueno et al. (2017) recommend to establish the criterion for determining if the citizen science obtained data is of sufficient quality to answer the research objectives. Species that are not similar to any other can be reliably identified. However, other species can be misidentified for similarity with other species. Therefore, unreliably identified species can only be diagnosed by comparing them with museum specimens, given that their diagnostic traits cannot be observed by photography and are easily misleading. For this reason, collected data should be supported with vouchers (e.g. museum specimens, call recordings) when it includes unreliably identified species.

In this contribution, we present a preliminary anuran inventory in the buffer area of La Amistad International Park performed by local people (citi- zens). Our results are discussed around the Citizen Science framework and their potential application for amphibian studies. Also, we discuss the uncertainty level of the species' identification of each species registered, taking into account if diagnostic or exclusive traits can be confirmed by photographs.

\section{Material and methods}

The study was carried out at La Palmira rural community, Coto Brus, province of Puntarenas, Costa Rica $\left(8^{\circ} 55^{\prime} 42.11^{\prime}\right.$ 'N, 82 $2^{\circ} 55^{\prime} 04.71$ '’W, 1092 masl). In January 2015, DG-H author visited La Palmira locality with the aim of perform a workshop to identify conservation threats and opportunities in the buffer area of La Amistad International Park. During the workshop, four local citizens were interested to know the local biodiversity, and being anurans our group of interest, we trained the local citizens to search, identify and photograph anurans. We accompanied and trained them in amphibian identification during two night walks, with the help of a field guide and cameras. Afterward, the local citizen were voluntarily interested to make an inventory of anurans in their locality. They performed the fieldwork alone, without assistance by professional scientists. During 2015 and 2016, the local citizens compiled photographs of amphibians they sighted during their daily farming activities. Two of the citizens (authors RMA and AMA) also directed their efforts in doing nine night walks (148 hours/person) exclusively in search of amphibians.

We used the rarefaction method to estimate anuran species richness, and the incidence based estimates for expected richness using the first order Jacknife method, which predicts the potential richness occurring in the study area. We performed these estimates with vegan package (Oksanen et al. 2017) for $\mathrm{R}$ language ( $\mathrm{R}$ Core Team 2017). We calculated a rank abundance with the logarithm of abundance using base 10 in BiodiversityR package (Kindt \& Coe 2005). Data and their analysis are available in the appendix.

\section{Results}

Local citizens registered 15 species of amphibians, all belonging to the order Anura. These species are represented in seven families and 11 genera. The maximum species richness was repre- 


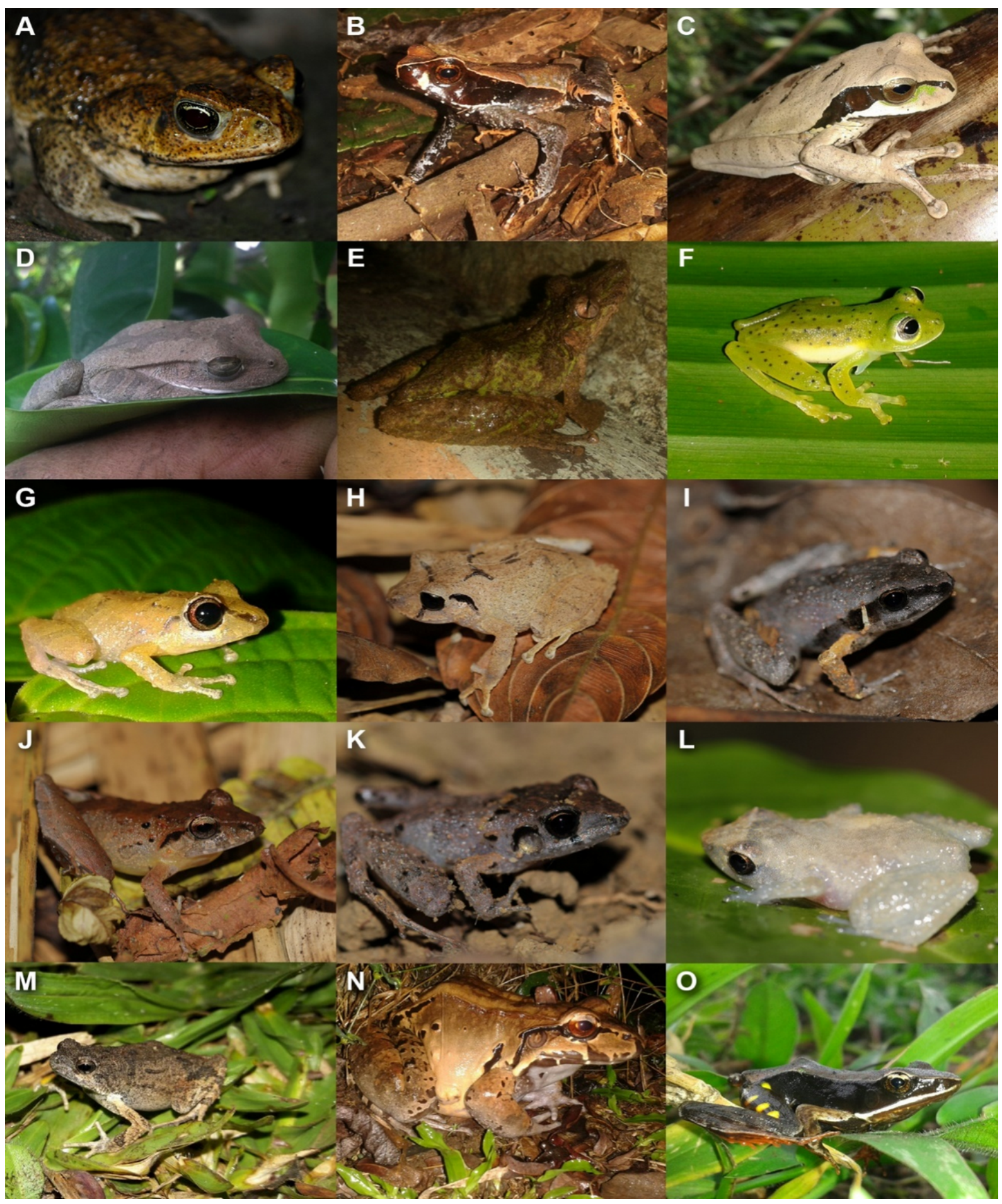

Figura 1. Anfibios registrados en el área de amortiguamiento del Parque Internacional La Amistad duranye el estudio piloto de ciencia ciudadana. Bufónidade: Rhinella horribilis (A), Rhaebo haematiticus (B); Hylidae: Smilisca phaeota (C), S. sordida (D), Scinax boulengeri (E); Centrolenidae: Espadarana prosoblepon (F); Craugastoridae: Pristimantis ridens (G), P. taeniatus (H), Craugastor gabbi (I), C. crassidigitus (J), C. stejnegerianus (K), Diasporus vocator (L); Leptodactylidae: Engystomops pustulosus (M); Leptodactylus savagei (N); Ranidae: Lithobates warszewitschii $(\mathrm{O})$.

Figure 1. Registered amphibians in the buffer area of La Amistad International Park during a Citizen Science pilot study. Bufonidae: Rhinella horribilis (A), Rhaebo haematiticus (B); Hylidae: Smilisca phaeota (C), S. sordida (D), Scinax boulengeri (E); Centrolenidae: Espadarana prosoblepon (F); Craugastoridae: Pristimantis ridens (G), P. taeniatus (H), Craugastor gabbi (I), C. crassidigitus (J), C. stejnegerianus (K), Diasporus vocator (L); Leptodactylidae: Engystomops pustulosus (M); Leptodactylus savagei (N); Ranidae: Lithobates warszewitschii $(\mathrm{O})$. 


\begin{tabular}{lccccc}
\hline \multicolumn{1}{c}{ Species } & \multicolumn{3}{c}{ Abundace Proportion } & $\begin{array}{c}\text { Confidence intervals (95\%) } \\
\text { upummulated } \\
\text { lower }\end{array}$ & $\begin{array}{c}\text { Acummuency } \\
\text { frequency }\end{array}$ \\
\hline Craugastor crassidigitus & 20 & 26.7 & 16.2 & 37.2 & 26.7 \\
Pristimantis ridens & 15 & 20 & 10.4 & 29.6 & 46.7 \\
Espadarana prosoblepon & 11 & 14.7 & 1.1 & 28.2 & 61.3 \\
Smilisca phaeota Cope, 1862 & 5 & 6.7 & 1.5 & 11.8 & 68 \\
Craugastor stejnegerianus (Cope, 1893) & 4 & 5.3 & -1.2 & 11.9 & 73.3 \\
Pristimantis taeniatus (Boulenger, 1912) & 4 & 5.3 & -0.5 & 11.1 & 78.7 \\
Leptodactylus savagei & 3 & 4 & -1.5 & 9.5 & 82.7 \\
Lithobates warszewitschii & 3 & 4 & 0.2 & 7.8 & 86.7 \\
Engystomops pustulosus & 2 & 2.7 & -1.7 & 7 & 89.3 \\
Rhaebo haematiticus & 2 & 2.7 & -1.7 & 7 & 92 \\
Rhinella horribilis & 2 & 2.7 & -1.7 & 7 & 94.7 \\
Craugastor gabbi Arias, Chaves, Crawford & 1 & 1.3 & -0.8 & 3.5 & 96 \\
\& Parra-Olea, 2016 & 1 & 1.3 & -0.8 & 3.5 & 97.3 \\
Diasporus vocator (Taylor, 1955) & 1 & 1.3 & -1.6 & 4.3 & 98.7 \\
Scinax boulengeri & 1 & 1.3 & -1.7 & 4.3 & 100 \\
Smilisca sordida (Peters, 1863) & & & & \\
\hline
\end{tabular}

Tabla 1. Rango de abundancia con el logaritmo de abundancia usando base 10 para especies de anuros de la comunidad rural de La Palmira, área de amortiguamiento del Parque Internacional La Amistad, Costa Rica.

Table 1. Rank abundance with the logarithm of abundance using base 10 for anuran species from La Palmira rural community, buffer area of La Amistad International Park, Costa Rica.

sented by the family Craugastoridae with five species, three of which belong to the genus Craugastor Cope, 1862 (Fig. 1). The species richness curve showed an asymptotic tendency (Fig. 2), although the extrapolated species richness estimate was $\sim 20$ species (first order Jacknife = 19.83; $\mathrm{SE}=3.23)$.

During the study, $75(\mathrm{SD}=5.74)$ anuran individuals were observed. Abundance was dominated by three species: Craugastor crassidigitus (Taylor, 1952), Pristimantis ridens (Cope, 1866) and Espararana prosoblepon (Boettger, 1892), with $61.3 \%$ of accumulated frequency (Table 1). In general, the rank abundance estimates were highly variable for all species, except for C. crassidigitus and P. ridens (Table 1).

Six species where considered to be reliably identified: Rhinella horribilis (Wiegmann, 1833), Rhaebo haematiticus (Cope, 1862), Scinax boulengeri (Cope, 1887), Leptodactylus savagei Heyer, 2005, Engystomops pustulosus (Cope, 1864) and Lithobates warszewitschii (Schmidt, 1857). The rest of the species' identification must be corroborated.

\section{Discussion}

Rhinella horribilis and Leptodactylus savagei in Costa Rica can only be misidentified during their

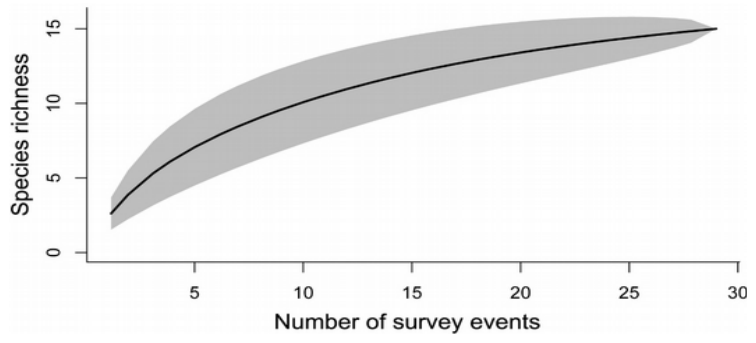

Figura 2. Curva de acumulación de especies rarificada de anuros para la comunidad rural de La Palmira, área de amortiguamiento del Parque Internacional La Amistad, Costa Rica. Polígono gris: intervalo de confianza 95\%.

Figure 2. Rarefied species accumulation curve of anuran for La Palmira rural community, buffer area of La Amistad International Park, Costa Rica. Grey polygon: confidence interval 95\%.

juvenile phase (Savage 2002). However, we considered them as reliably identified because the photographs represent adult individuals. Engystomops pustulosus is the only species of the genus reported for Costa Rica, but it can be misidentified with a young Bufonidae. The obtained photograph of E. pustulosus shows no basal webbing between the toes nor bony crests on the head, so it cannot be misidentified. Rhaebo haematiticus, Scinax boulengeri and Lithobates warszewitschii cannot be misidentified with other species in their distribution (Savage 2002, Leenders 2016). Specifically, S. boulengeri may be confused with Isthmohyla calypsa (Lips, 1996) (by inexperienced people), but the record is $700 \mathrm{~m}$ under the 
species' lowest known distribution limit; also, young $R$. haematiticus could be misidentified with other young bufonids. Espadarana prosoblepon has diagnostic traits identifiable with photographs (such as the presence of well-developed humeral spines in males, females could be misindentified) and the study area coincides with its distribution. Smilisca phaeota cannot be misidentified with similar species such as Smilisca baudinii (Duméril \& Bibron, 1841), Smilisca puma (Cope, 1885) and Osteopilus septentrionalis (Duméril \& Bibron, 1841) since their distribution does not coincide in the southern Pacific slope of Costa Rica.

Smilisca sordida is highly variable and therefore is difficult to identify (Savage 2002, Leenders 2016). However, it can only be misidentified in localities where $S$. sila is sympatric. On the other hand, the genera Craugastor, Pristimantis Jiménez de la Espada, 1870 and Diasporus Hedges, Duellman \& Heinicke, 2008 are highly polymorphic, therefore they are difficult to diagnose (Savage 2002, Leenders 2016), even with museum specimens.

During this pilot study, we recognized two important records of anurans in the study area. First, the altitudinal extension range of $S$. boulengeri. According to literature, this species is distributed from sea level to 700 masl (Savage 2002, Solís et al. 2008, Leenders 2016), but herein we report an increase in altitudinal distribution $300 \mathrm{~m}$ above the previous highest record. Moreover, $P$. taeniatus is a species known mainly from western Colombia and Panama, and here we present the second report for Costa Rica with confirmed presence in La Amistad International Park buffer area. The presence in the country was mentioned by Leenders (2016) without voucher neither a particular locality. Also, this report is corroborated by specimen vouchers stored in Zoology Museum of the Universidad de Costa Rica (Bolaños et al. 2011).

Citizen obtained data is not incorporated to conservation since the usual perception is that it has scarce quality and rigor (Burgess et al. 2017). Although this perception is in some cases true, it cannot be taken as a generalization. The current contribution demonstrates that citizen-obtained amphibian data can be useful and reports must not be discarded, especially when these are from isolated localities, which researchers usually do not visit. However, corroboration is necessary to offer confidence to researchers and policy makers for incorporating these results in planning and executing conservation and management actions in an area, as recommended by Wiggins et al. (2013).

Accurate species identification is key to initiate amphibian ecology studies. In this pilot program, we show the potential use of Citizen Science for amphibian studies in the buffer area of $\mathrm{La}$ Amistad International Park. However, we recommend to evaluate the certainty and reliability of the species' identification in order to obtain high data quality and rigor to carry out research by this means. Also, a potential project of Citizen Science must surpass standardized methods issues and survey bias, elements usually criticized in this practices (Dickinson et al. 2010). The fact that data collection depends on citizens' (local people) daily activities can complicate survey standardization. Therefore, we recommend to establish protocols, according to different contexts, in order to ensure training for interested local inhabitants who have the facility to share their photos and data with scientists. These protocols should be adaptable to the citizens' time and effort availability, as well as volunteers' conditions, because rural context differ of other initiatives (near cities) where more potential volunteers recruitment is possible.

In many rural areas in the Neotropic the citizens that could be involved in research are farmers. Also, the data they can provide is usually from isolated areas, and therefore can be very useful for contributing on amphibian knowledge. Despite data being based on photographs, it has the potential to lead scientific researchers to explore new areas.

\section{Acknowledgements}

This project was partially funded by Finca Las Alturas del Bosque Verde and ProCAT International. Thanks to David Lugo for valuable comments in the English version of the manuscript. Two anonymous reviewers made important inputs to the manuscript.

\section{References}

Aceves-Bueno E, Adeleye AS, Feraud M, Huang Y, Tao M, Yang Y \& Anderson SE. 2017. The accuracy of citizen science data: A quantitative review. The Bulletin of the Ecological Society of America 98(4): 278-290. 
AmphibiaWeb. 2018. <https://amphibiaweb.org> University of California, Berkeley, CA, USA. Available: https://amphibiaweb.org/resources/id.html (accessed 8-II-2018).

Bhattacharjee Y. 2005. Citizen scientists supplement work of Cornell researchers. Science 308: 14021403

Bolaños F, Savage JM \& Chaves G. 2011. Anfibios y reptiles de Costa Rica. Listas zoológicas actualizadas UCR. Museo de Zoología UCR. San Pedro, Costa Rica. Available: http://museo.biologia.ucr.ac. $\mathrm{cr} /$ Listas/LZAPublicaciones.htm (accessed 28-VI2017).

Burgess HK, DeBey LB, Froehlich HE, Schmidt N, Theobald EJ, Ettinger AK, HilleRisLambers J, Tewksbury J \& Parrish JK. 2017. The science of citizen science: Exploring barriers to use a primary research tool. Biological Conservation 208: 113-120.

Chandler M, See L, Copas K, Bonde AMZ, Claramunt López B, Danielsen F, Legind JK, Masinde S, MillerRushing AJ, Newman G, Rosemartin A \& Turak E. 2017. Contribution of citizen science towards international biodiversity monitoring. Biological Conservation 213: $280-294$.

Dickinson J, Zuckerberg B \& Bonter DN. 2010. Citizen science as an ecological research tool: challenges and benefits. Annual Review of Ecology, Evolution, and Systematics 41: 149-172.

Kindt R \& Coe R. 2005. Tree diversity analysis. A manual and software for common statistical methods for ecological and biodiversity studies. Nairobi: World Agroforestry Centre (ICRAF).

Leenders T. 2016. Amphibians of Costa Rica, a field guide. New York: A Zona Tropical Publication, Cornell University Press.

Lepczyk CA. 2005. Integrating published data and citizen science to describe bird diversity across a landscape. Journal of Applied Ecology 42: 672-677.

Menacho-Odio RM. 2015. Colisión de aves contra ventanas en Costa Rica: conociendo el problema a partir de datos de museos, ciencia ciudadana y el aporte de biólogos. Zeledonia 19(1): 10-21.

Oksanen J, Blanchet FG, Friendly M, Kindt R, Legendre P, McGlinn D, Minchin PR, O'Hara RB, Simpson GL, Solymos P, Henry M, Stevens H, Szoecs E \& Wagner H. 2017. vegan: Community Ecology Package. R package version 2.4-4. Available: https://CRAN.Rproject.org/package=vegan.

Palmer JRB, Oltra A, Collantes F, Delgado JA, Lucientes
J, Delacour S, Bengoa M, Eritja R \& Bartumeus F. 2017. Citizen science provides a reliable and scalable tool to track disease-carrying mosquitoes. Nature Communications 8: 916.

Pittman SE \& Dorcas ME. 2006. Catawba River corridor coverboard program: a citizen science approach to amphibian and reptile inventory. Journal of the North Carolina Academy of Science 122(4): 142-151.

R Core Team. 2017. R: A language and environment for statistical computing. R Foundation for Statistical Computing, Vienna, Austria. Available: https:// www.R-project.org/.

Savage JM. 2002. The amphibians and reptiles of Costa Rica: a herpetofauna between two continents, between two seas. University of Chicago Press.

Schmeller DS, Henry PY, Julliard R, Gruber B, Clobert J, Dziock F, Lengyel S, Nowicki P, Deri E, Budrys E, Kull T, Tali K, Bauch B, Settele J, Van Swaay C, Kobler A, Babij V, Papastergiadou E \& Henle K. 2009. Advantages of volunteer-based biodiversity monitoring in Europe. Conservation Biology 23(2): 307-316.

Solís F, Ibáñez R, Chaves G, Savage J, Jaramillo C, Fuenmayor Q, Lynch J, Castro F \& Bolaños F. 2008. Scinax boulengeri. The IUCN red list of threatened species. Version 2016.3. Available: www.iucnred list.org (accessed 1-XI-2016).

Sullivan BL, Wood CL., Iliff MJ, Bonney RE, Fink D \& Kelling S. 2009. eBird: A citizen-based bird observation network in the biological sciences. Biological Conservation 142(10): 2282-2292.

Sullivan BL, Aycrigg JL, Barry JH, Bonney RE, Bruns N, Cooper CB, Damoulas T, Dhondt AA, Dietterich T, Farnsworth A, Fink D, Fitzpatrick JW, Fredericks T, Gerbracht J, Gomes C, Hochachka WM, Illif MJ, Lagoze C, La Sorte FA, Merrifield M, Morris W, Phillips TB, Reynolds $M$, Rodewald $A D$, Rosenberg KV, Trautmann NM, Wiggins A, Winkler DW, Wong W-K, Wood CL, Yu Jun \& Kelling S. 2014. The eBird enterprise: an integrated approach to development and application of citizen science. Biological Conservation 169: 31-40.

Wiggins A, Bonney R, Graham E, Henderson S, Kelling S, LeBuhn G, Littauer R, Lotts K, Michener W, Newman G, Russel E, Stevenson R, Welzen J. 2013. Data management guide for public participation in scientific research. DataONE. Available: https://www. dataone.org/sites/all/documents/DataONE-PPSRDataManagementGuide.pdf (accessed 12-II-2017). 


\section{Appendix}

The next data are made freely available by the authors at:

https://github.com/biodiego88/Material_suplementario_pub

\section{R script}

\#\#\#Data Analysis: Gómez-Hoyos et al. Anuran inventory in a locality of the buffer area of La Amistad International Park, Costa Rica: pilot study for Citizen Science application. Anales de Biologia\#\#\#

\#\#\#species accumulation curve\#\#\#

\#R Package\#

library (vegan)

\#directory files\#

setwd ("D:/NUEVO_DIEGO/R_analysis/Comunidades/citizen_sc")

\#data\#

a<-read.delim("citizen_sc2.txt")

\#data frame\#

b<-as.data.frame (tapply (a\$abundancia, list (a\$esfuerzo, a\$especie), sum))

$b[]<-$ lapply $(b$, function $(x) \operatorname{replace}(x$, is.na $(x), 0))$

head (b)

\#rarified Species accumulation curve

$c<-\operatorname{specaccum}(b$, method='rarefaction', permutations $=1000$, gamma $=$ "jack1")

$\mathrm{C}$

plot (c, ci.type="poly", col="black", lwd=2, ci.lty=@, ci.col="grey", ylim=c $(\odot, 16))$

\# number of unobserved species \#

specpool (b, smallsample = TRUE)

\#\#\#pecies accumulation curve\#\#\#

\# R Package \#

library (BiodiversityR)

\# Rank abundance curve

RankAbun. $1<-$ rankabundance $(b, t=q t(0.975, d f=17-1))$

RankAbun. 1

rankabunplot (RankAbun.1, scale='logabun', addit=FALSE, specnames=F)

citation ("vegan")

\section{Abundance of species}

unobserved species (function specpool)

$\begin{array}{ccccccccc} & \text { Species } & \text { chao } & \text { chao.se } & \text { jack1 } & \text { jack1.se } & \text { jack2 } & \text { boot } & \text { boot.se } \\ \text { All } & 15 & 19.02299 & 4.729202 & 19.82759 & 3.233299 & 21.78941 & 17.30036 & 1.871637\end{array}$

rank abundance (function rankabundance)

\begin{tabular}{lcccccc} 
& \multicolumn{7}{c}{ Rank } & abundance & proportion & plower & pupper & accumfreq \\
Craugastor_crassidigitus & 1 & 20 & 26.7 & 16.2 & 37.2 & 26.7 \\
Pristimantis_ridens & 2 & 15 & 20.0 & 10.4 & 29.6 & 46.7 \\
Espadarana_prosoblepon & 3 & 11 & 14.7 & 1.1 & 28.2 & 61.3 \\
Smilisca_phaeota & 4 & 5 & 6.7 & 1.5 & 11.8 & 68.0 \\
Craugastor_stejnegerianus & 5 & 4 & 5.3 & -1.2 & 11.9 & 73.3 \\
Pristimantis_taeniatus & 6 & 4 & 5.3 & -0.5 & 11.1 & 78.7 \\
Leptodactylus_savagei & 7 & 3 & 4.0 & -1.5 & 9.5 & 82.7 \\
Lithobates_warszewitschii & 8 & 3 & 4.0 & 0.2 & 7.8 & 86.7 \\
Engystomops_pustulosus & 9 & 2 & 2.7 & -1.7 & 7.0 & 89.3 \\
Rhaebo_haematiticus & 10 & 2 & 2.7 & -1.7 & 7.0 & 92.0 \\
Rhinella_horribilis & 11 & 2 & 2.7 & -1.7 & 7.0 & 94.7 \\
Craugastor_gabbi & 12 & 1 & 1.3 & -0.8 & 3.5 & 96.0 \\
Diasporus_vocator & 13 & 1 & 1.3 & -0.8 & 3.5 & 97.3 \\
Scinax_boulengeri & 14 & 1 & 1.3 & -1.6 & 4.3 & 98.7 \\
Smilisca_sordida & 15 & 1 & 1.3 & -1.7 & 4.3 & 100.0
\end{tabular}




\section{Citizen data}

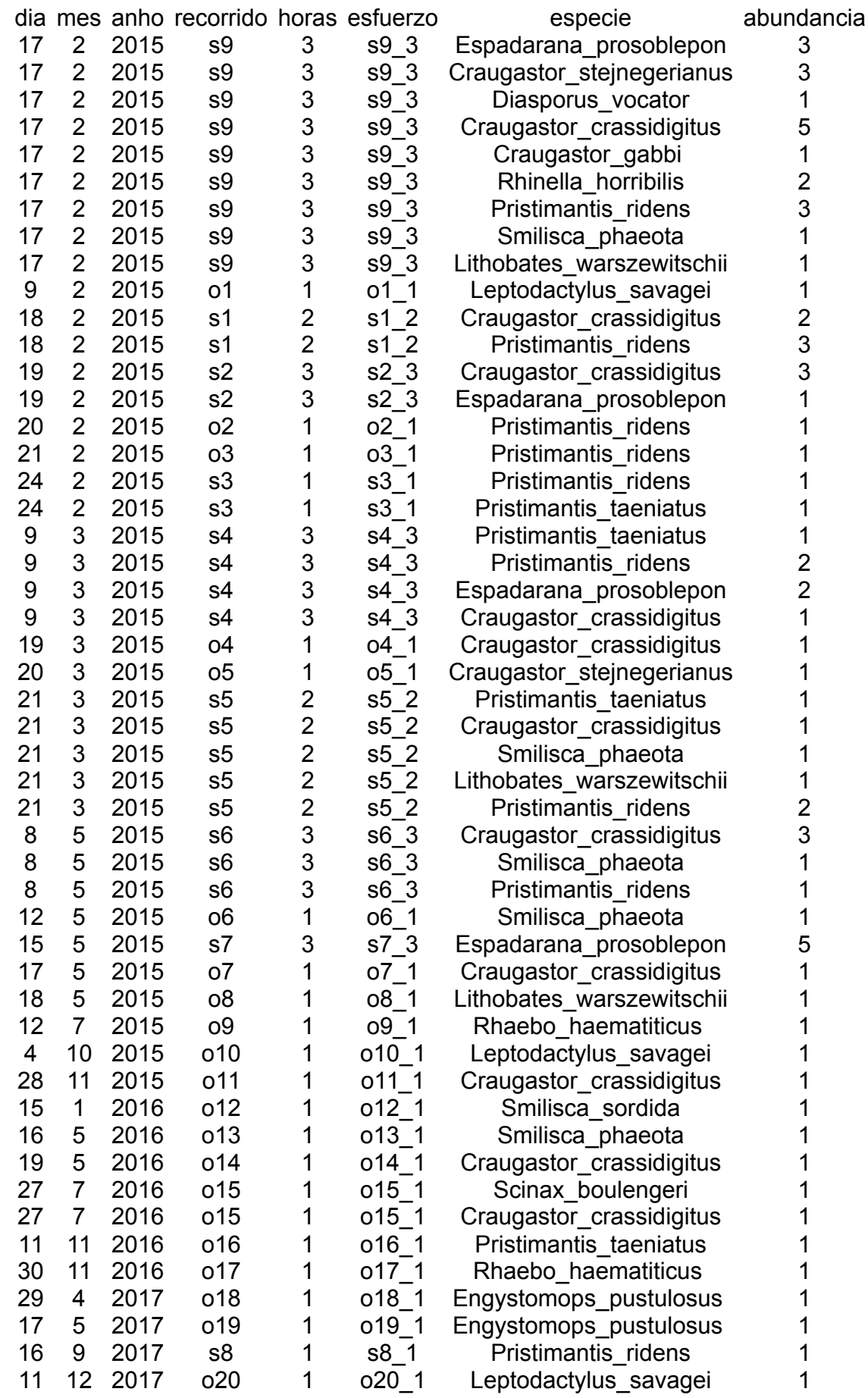

